\title{
Use of Water Injection Technique to Improve the Combustion Efficiency of the Spark-Ignition Engine: A Model Study
}

\author{
Osama H. Ghazal', Gabriel Borowski ${ }^{*}$ \\ 1 Department of Mechanical Engineering, Applied Science Private University, Al Arab st. 21, 11931 Amman, \\ Jordan \\ 2 Faculty of Environmental Engineering, Lublin University of Technology, ul. Nadbystrzycka 40B, 20-618 Lublin, \\ Poland \\ * Corresponding author's e-mail: g.borowski@pollub.pl
}

\begin{abstract}
In the paper, the effect of water injection and different air/fuel ratio on the gasoline engine performance and emissions was investigated theoretically. A four cylinder SI engine model was built using GT-Power professional software. The gasoline fuel was injected directly to the cylinder and water was injected into the intake manifold with different mass flow rate. The calculated engine parameters were: cylinder pressure and temperature, brake torque, brake power, mean effective pressure, thermal efficiency, carbon monoxide, hydrocarbon, and nitrogen oxide emissions. The results of simulations show that the increased water mass flow rate resulted in an improved engine performance and decreased emissions compared to neat gasoline fuel. However, we found that the excessive increase of the water amount inside the cylinder resulted in a deteriorated engine performance and, consequently, poor combustion efficiency.
\end{abstract}

Keywords: water injection, combustion, emissions, engine modeling.

\section{INTRODUCTION}

The internal combustion (IC) engine operating on fossil fuel is one the main sources of air pollution. Therefore, the major challenge faced by automobile manufacturers is to reduce the engine emissions and increase their efficiency. Recently, the low temperature combustion technique has been considered as one of the promising technologies to reduce the in-cylinder temperature and engine emissions. Water injection technique is a good technology due to its ability to decrease the combustion temperature inside the cylinder by absorbing high amount of heat released from combustion. In addition, the cooling of the engine parts increased the engine lifespan, and prevented the load shock inside the engine.

Many researchers have investigated the effect of water injection on the IC engine due to improved engine efficiency and reduced emissions [Berni et al. 2015, Breda et al. 2015, Brusca and Lanzafame 2003, Hoppe et al. 2016, Harrington 1982, Kim et al. 2016, Mathur et al. 1992, Parley 2011, Peters and Stebar 1976, Weatherford and Quillian 1970]. Boretti [2013] studied the effect of water on a turbocharged engine and observed a reduction in the intake gas temperature, resulting in improved engine power and fuel efficiency. Totala et al. [2013] observed a reduction of carbon monoxide (CO) and hydrocarbon (HC) emissions when a water/ methanol mixture was introduced to the gasoline engine. Berni et al. [2015] confirmed theoretically the effect of water/fuel mixture percentage on the engine knock resistance. The study on the effect of intake manifold water injection was performed by Tauzia et al. [2010]. The extension of the ignition delay compound with $\mathrm{NO}_{\mathrm{x}}$ reduction was observed when water was added to the mixture. Tesfa et al. [2011] investigated the effect of water injection in an IC engine operating on biodiesel fuel. They observed a significant reduction of nitrogen oxide $\left(\mathrm{NO}_{\mathrm{x}}\right)$ with engine performance deterioration. Subramanian [2011] analyzed the effect of water injection on engine emissions. 
The goal of this work was to theoretically investigate the effect of different water mass flow rates and air/fuel ratio on the engine emissions and performance as well. A four cylinder SI engine model was built and simulated. Water was injected to the intake manifold with various mass flow rates ranging from $0.5 \mathrm{~g} \cdot \mathrm{s}^{-1}$ to $1.5 \mathrm{~g} \cdot \mathrm{s}^{-1}$. The gasoline fuel was injected directly to the combustion chamber. The engine speed was constant for all runs, amounting to $2000 \mathrm{rpm}$, and the engine was operated at full load. The model was validated using the data available from the literature.

\section{MODEL DESCRIPTION}

A four cylinder direct injection spark ignition engine model is presented in Figure 1. The gasoline fuel was injected directly to the cylinder with a mass flow rate of $0.65 \mathrm{~g} \cdot \mathrm{s}^{-1}, 0.56 \mathrm{~g} \cdot \mathrm{s}^{-1}$ and $0.49 \mathrm{~g} \cdot \mathrm{s}^{-1}$ to obtain the air/fuel ratio (AFR) at $12.5,14.5$ and 16.5 , respectively, for dry gasoline combustion. The water was injected to the intake manifold with mass flow rate varying from 0.5 to $1.5 \mathrm{~g} \cdot \mathrm{s}^{-1}$ and temperature of $300 \mathrm{~K}$. The neat gasoline fuel combustion was also investigated in order to compare with the gasoline/water injection parameters. The engine speed was $2000 \mathrm{rpm}$ and it was kept constant for all simulation runs. The AFR was varied as shown in Figure 2. The injected water to the intake port absorbs heat and reduces the intake charge temperature resulting in an increased volumetric efficiency and amount of air introduced to the cylinder causing the increase of AFR. The gasoline injected mass increased along with the air mass.

The GT-Power program solves the conservation equations using a 1-dimensional model [http://www.gtisoft.com]. The Woschni model was used to calculate the heat transfer in the combustion chamber. We used the SI Wiebe combustion model, which imposes the burn rate for SI engine using the Wiebe function. However, the Wiebe constants should be determined experimentally. The engine specifications are presented in Table 1. The engine initial conditions are presented in Table 2. The operation conditions are illustrated in Table 3. The model was validated using the data available from the literature, and a good agreement was obtained.

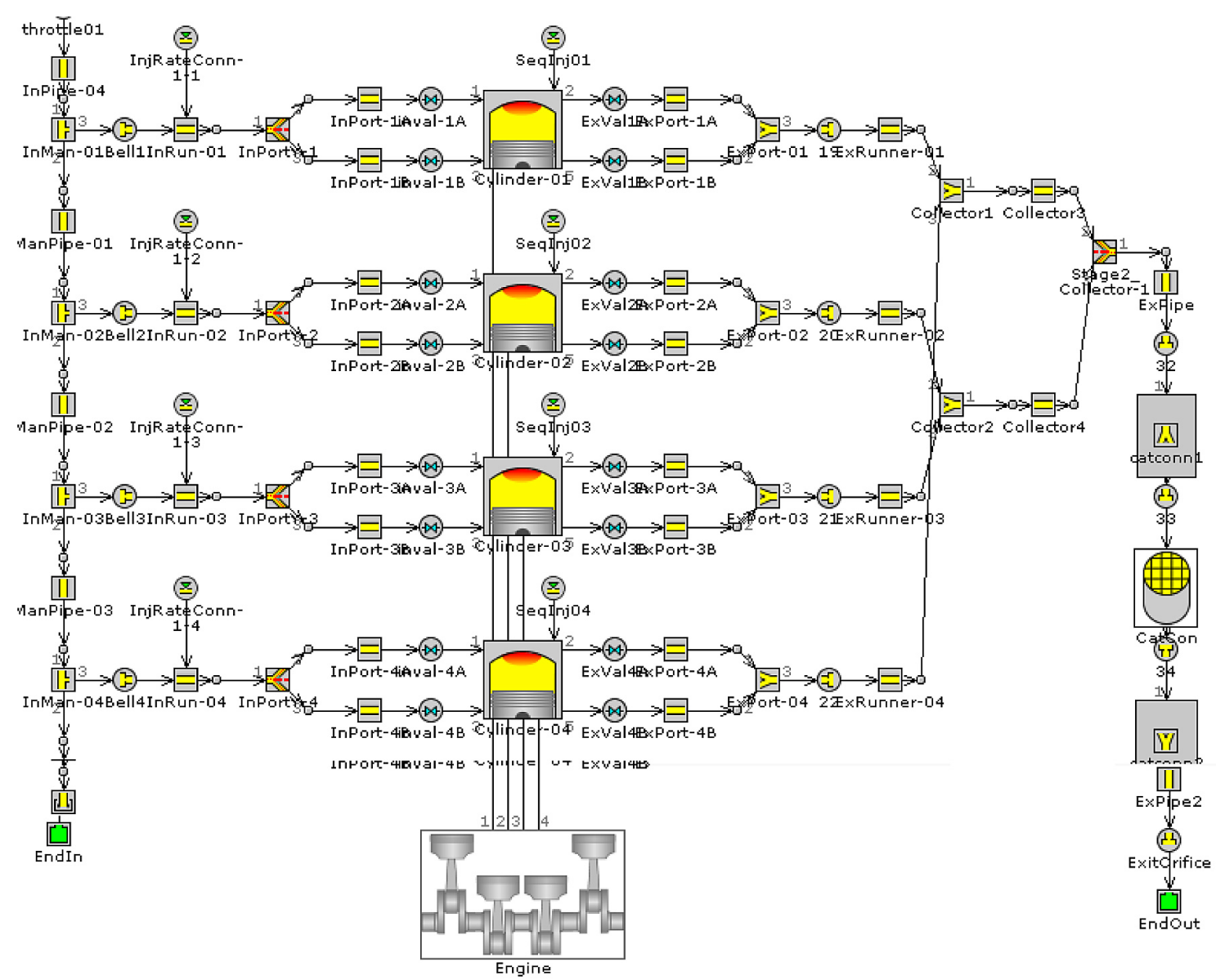

Figure 1. Four cylinder engine model using GT-Power code 


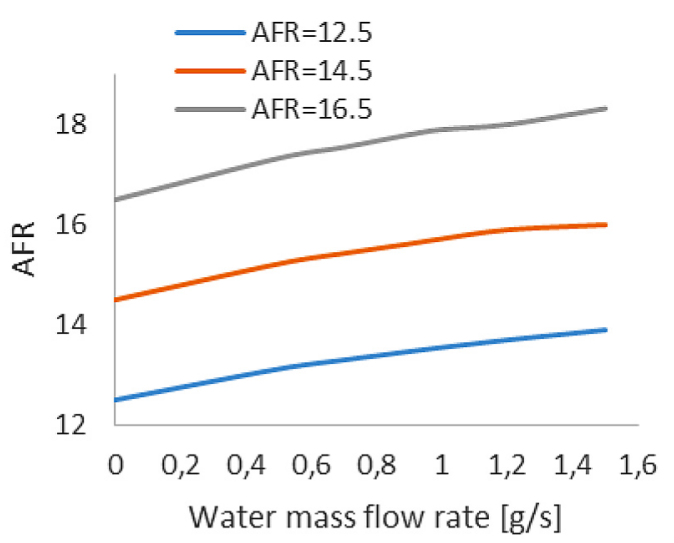

Figure 2. Air/fuel ratio variation with water mass flow rate

Table 1. Engine geometry

\begin{tabular}{|l|c|c|}
\hline \multicolumn{1}{|c|}{ Parameter } & Unit & Value \\
\hline Bore & $\mathrm{mm}$ & 85 \\
\hline Stroke & $\mathrm{mm}$ & 87 \\
\hline Connect rod length & $\mathrm{mm}$ & 180 \\
\hline Piston pin offset & $\mathrm{mm}$ & 0 \\
\hline Number of cylinders & - & 4 \\
\hline Compression ratio & - & 10 \\
\hline Bore/stroke & - & 0.97 \\
\hline Inlet valve close & ${ }^{\circ} \mathrm{CA}$ & -105 \\
\hline Inlet valve open & ${ }^{\circ} \mathrm{CA}$ & 308 \\
\hline Exhaust valve close & ${ }^{\circ} \mathrm{CA}$ & 385 \\
\hline Exhaust valve open & ${ }^{\circ} \mathrm{CA}$ & 128 \\
\hline
\end{tabular}

Table 2. Engine initial conditions

\begin{tabular}{|l|c|c|}
\hline \multicolumn{1}{|c|}{ Parameter } & Unit & Value \\
\hline Initial pressure & bar & 1 \\
\hline Initial temperature & $\mathrm{K}$ & 300 \\
\hline Head temperature & $\mathrm{K}$ & 575 \\
\hline Piston temperature & $\mathrm{K}$ & 575 \\
\hline Cylinder temperature & $\mathrm{K}$ & 400 \\
\hline
\end{tabular}

Table 3. Engine operating conditions

\begin{tabular}{|l|c|c|}
\hline \multicolumn{1}{|c|}{ Parameter } & Unit & Value \\
\hline Engine speed & $\mathrm{rpm}$ & 2000 \\
\hline Start of combustion & ${ }^{\circ} \mathrm{CA}$ & -20 \\
\hline Start of injection & ${ }^{\circ} \mathrm{CA}$ & 365 \\
\hline $\begin{array}{l}\text { Reference pressure of volume } \\
\text { effect }\end{array}$ & $\mathrm{bar}$ & 1 \\
\hline $\begin{array}{l}\text { Reference temperature of } \\
\text { volume effect }\end{array}$ & $\mathrm{K}$ & 300 \\
\hline Mean piston velocity & $\mathrm{m} \cdot \mathrm{s}^{-1}$ & 5.6 \\
\hline
\end{tabular}

\section{Conservation equations}

The conservation equations solved by GTPower code are presented below [Lanzafame 1999]:
Continuity:

Energy: $\quad \frac{d m}{d t}=\sum_{\text {boundries }} \dot{m}$

$\frac{d(m e)}{d t}=-p \frac{d V}{d t}+\sum_{\text {boundies }}(m H)-h A_{s}\left(\dot{T}_{\text {fluld }}-T_{\text {wall }}\right)$

Enthalpy:

$\frac{d(\rho H V)}{d t}=\sum_{\text {boundies }}(\dot{m} H)+V \frac{d p}{d t}-h A_{s}\left(T_{\text {fluld }}-T_{\text {wall }}\right)$

Momentum:

$\frac{d \dot{m}}{d t}=\frac{d p A+\sum(\dot{m} u)-4 C_{f} \frac{\rho u|u|}{2} \frac{d x A}{D}-K_{p}\left[\frac{1}{2} \rho u|u|\right] A}{d x}$

where: $m$-mass of fuel injected $(\mathrm{kg})$,

$p$ - pressure in the cylinder $(\mathrm{Pa})$,

$V$ - volume of the cylinder $\left(\mathrm{m}^{3}\right)$,

$T$ - temperature of the cylinder contents $(\mathrm{K})$,

$H$ - enthalpy $\left(\mathrm{J} \cdot \mathrm{kg}^{-1}\right)$,

$C_{f}$ - specific heat $\left(\mathrm{J} \cdot \mathrm{kg}^{-1} \cdot \mathrm{K}^{-1}\right)$,

$\rho$-density of fuel $\left(\mathrm{kg} \cdot \mathrm{m}^{-3}\right)$.

\section{Heat transfer model}

The heat transfer model used in the simulation was the Woschni model, which calculates the heat transfer according to the following equation [Lanzafame 1999]:

$h=\frac{A \cdot p^{0.8}}{T^{0.5} \cdot D_{c y l}^{0.2}}\left(B \cdot \bar{U}_{p i s t o n}+C \cdot \frac{T_{s o c} \cdot V \cdot\left(p-p_{\text {motor }}\right)}{p_{s o c} \cdot V_{s o c}}\right)^{0.8}$

where: $A, B, C$ are Woschni coefficients.

Thus the heat transfer per unit area of cylinder wall is defined as:

$$
\frac{d Q}{F}=h \cdot\left(T_{\text {gas }}-T_{\text {wall }}\right)
$$

where: $d Q / F$ - heat transfer per unit area $\left(\mathrm{W} \cdot \mathrm{m}^{-2}\right)$.

\section{RESULTS AND DISCUSSION}

\section{The effect of water injection on engine performance}

Figures 3 and 4 show the effect of water injection and AFR on the engine brake specific fuel consumption and engine power. The engine fuel consumption decreased as the mass of the injected 


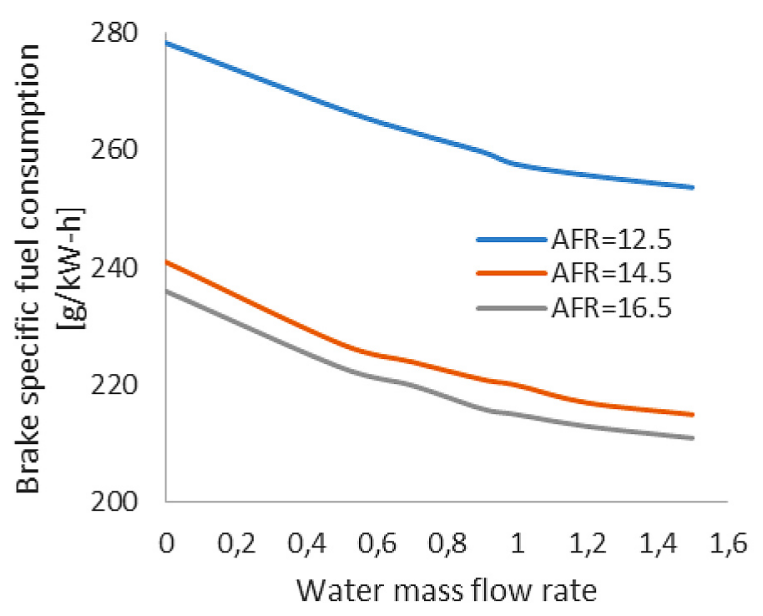

Figure 3. Effect of water injection on fuel consumption for different AFR

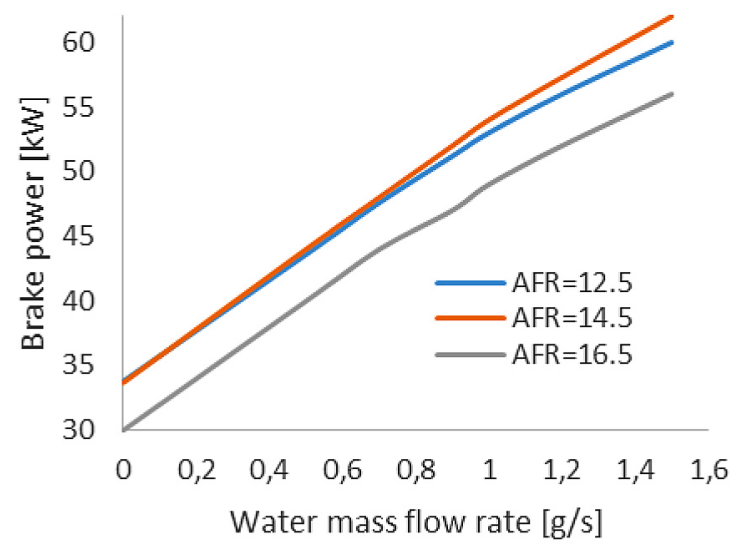

Figure 4. Effect of water injection on engine brake power for different AFR

water increased, as shown in Figure 3. This is due to the reduction of the exhaust gas temperature and shifting toward stoichiometric combustion.

The engine power also improved when the water mass increased, as illustrated in Figure 4. This is due to the increase in the AFR as well as raised amount of injected fuel and improved thermal efficiency. Besides, if small water droplets were introduced to cylinder, they could absorb the heat and decrease the cylinder pressure during the compression stroke resulting in a reduction of compression work. Another reason for the engine power improvement could be the combustion of the mixture under stoichiometric conditions caused by the exhaust gases temperature reduction due to the injected water. Similar results were obtained by Boretti [2013].

The injected water mass positively affects the engine brake effective pressure and brake thermal efficiency, compared to neat gasoline fuel, as seen in Figures 5 and 6 . The thermal efficiency increased along with water flow mass due to the increased working fluid mass caused by water droplets evaporation which turn into high pressure steam. Besides, when the injected water mass flow rate is $1.5 \mathrm{~g} \cdot \mathrm{s}^{-1}$ the reduction in the exhaust gas temperature is around $120{ }^{\circ} \mathrm{C}$, which results in increasing the thermal efficiency by about $10 \%$ for stoichiometric and lean mixtures. Similar results were presented by Lumsden et al. [1997].

The mean effective pressure is affected by the spark timing. When water mass increased, the advanced timing should be increased as well and consequently the engine effective pressure should be improved. Moreover, the brake effective pressure will increase along with the water mass due to knock mitigation caused by the introduced water. Furthermore, the injected water causes the combustion retardation, resulting in closer constant volume combustion leading to an increase in the brake effective pressure. This is in good agreement with Kim et al. [2016]. In general, the engine performance improved with water injection for different AFR (Figures 7 and 8).

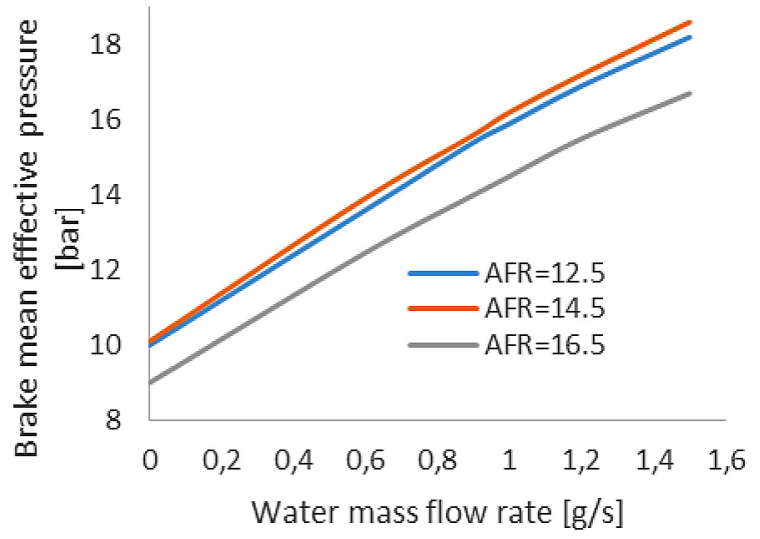

Figure 5. Effect of water injection on engine pressure

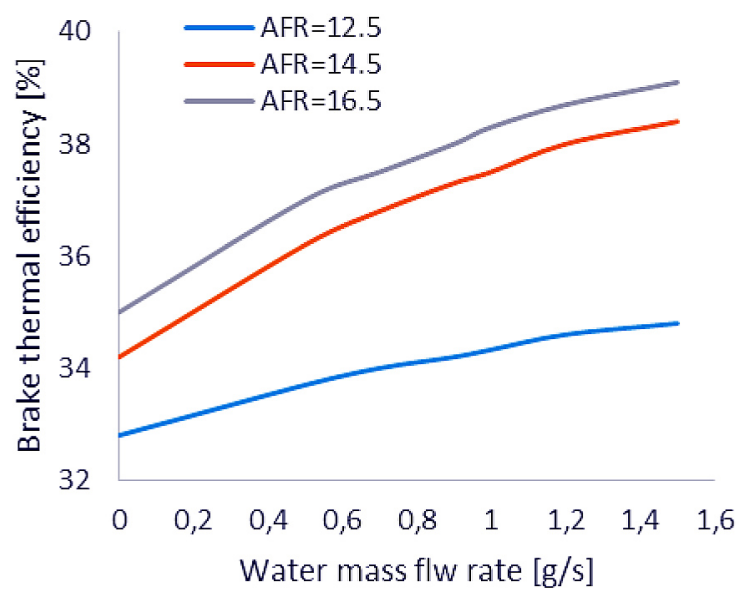

Figure 6. Effect of water injection on engine thermal efficiency 


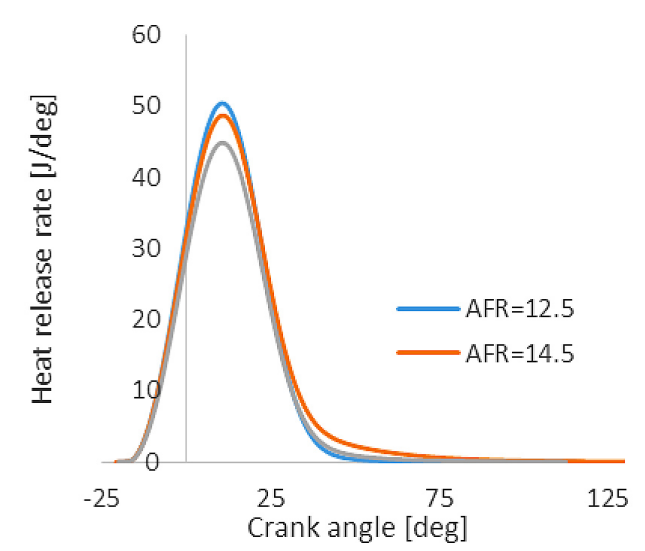

Figure 7. Heat release rate versus AFR for dry combustion

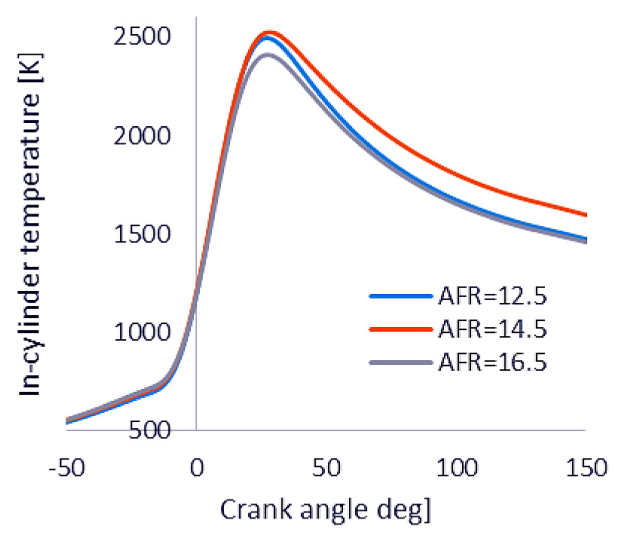

Figure 8. The cylinder temperature for different AFR
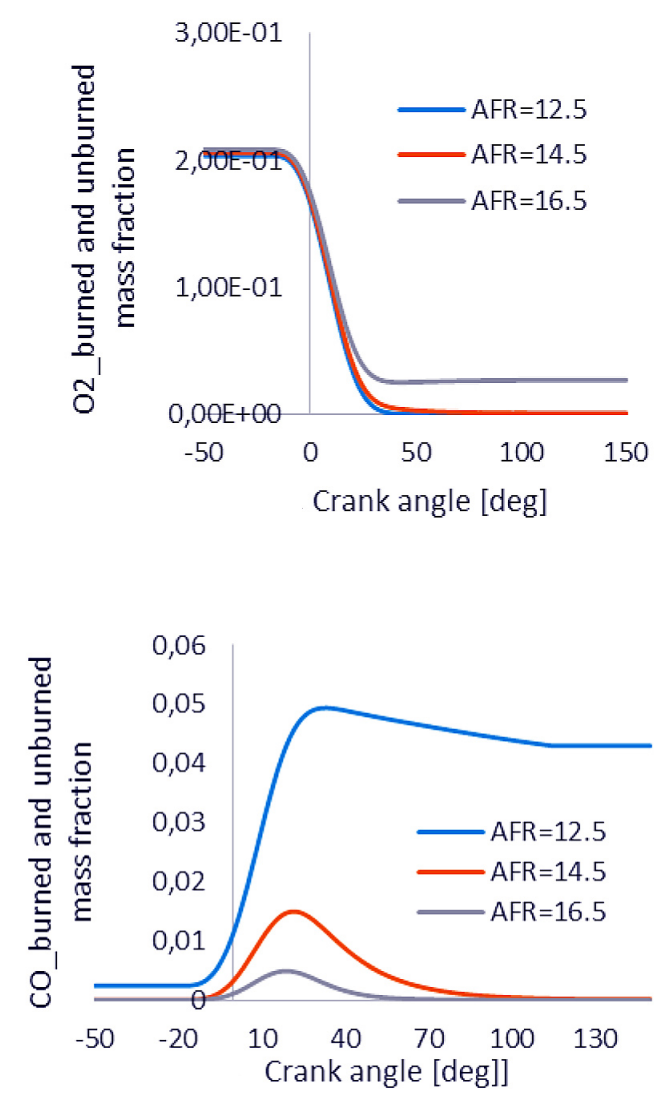

Figure 9. Engine emissions characteristics versus crank angle for different AFR (dry combustion)

\section{The effect of water injection on engine emissions}

The extended Zeldovich model was used to calculate the $\mathrm{NO}_{\mathrm{x}}$ emissions. The equations are shown below [Lanzafame 1999]:

$$
\begin{gathered}
\mathrm{O}+\mathrm{N}_{2}=\mathrm{NO}+\mathrm{N} \\
\mathrm{N}+\mathrm{O}_{2}=\mathrm{NO}+\mathrm{O} \\
\mathrm{N}+\mathrm{OH}=\mathrm{NO}+\mathrm{H}
\end{gathered}
$$

The $\mathrm{O}_{2}$ concentration variation as a function of crank angle was presented in Figure 9a. The characteristic of $\mathrm{NO}$ emissions for different AFR is presented in Figure 9b. The effect of water mass flow rate on $\mathrm{NO}$ emissions for different mixtures was illustrated on Figure 10. As shown, the nitrogen oxide amount decreased significantly when the water mass flow rate increased for the stoichiometric and lean mixtures. This is due to high cylinder temperature caused by complete combustion and the exceeded amount of oxygen available to react with nitrogen. As it is known, the NO formation required oxygen, nitrogen and high local temperature. Another reason for high NO emissions for lean combustion could by the improper spark timing which should be adjusted according to the AFR and
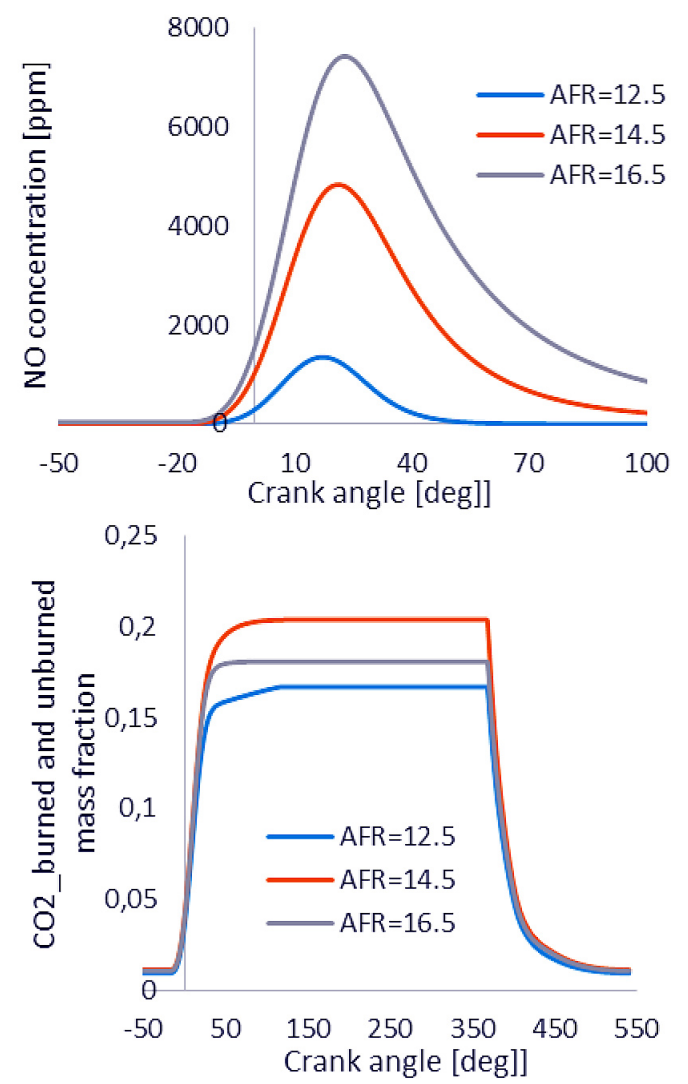


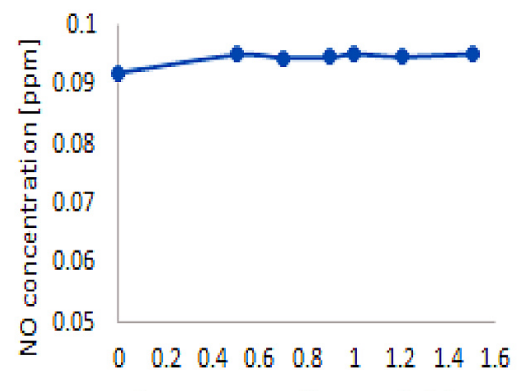

a. Water mass flow rate $[\mathrm{g} / \mathrm{s}]$
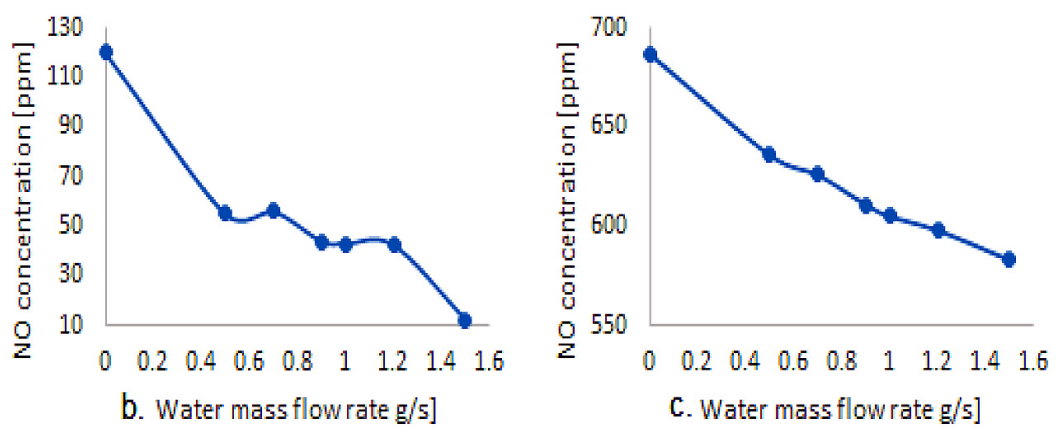

Figure 10. Effect of water injection on NO emissions (dry AFR, $a=12.5, b=14.5$, and $c=16.5$ respectively)

injected water mass. The increase of the injected water amount resulted in a better control of engine emissions. This observation is in agreement with Mathur et al. [1992] who performed a reduction of $\mathrm{NO}_{\mathrm{x}}$ emissions as the water flow rate increased. Furthermore, Adnan et al. [2012] reported that the increased water injection duration resulted in an elevated water amount in the mixture and, consequently, reduced $\mathrm{NO}_{x}$ emission. Moreover, when the water mass increased, the maximum cylinder temperature decreased, resulting in lower $\mathrm{NO}_{x}$ emission. For the stoichiometric mixture, the reduction of $\mathrm{NO}_{x}$ emissions is about $90 \%$ for $1.5 \mathrm{~g} \cdot \mathrm{s}^{-1}$ water mass, compared to neat gasoline fuel.

Figure 11 illustrates the hydrocarbons concentration versus the water mass flow rate for different mixtures. As it can be seen, the increased of water mass resulted in decreased HC emissions due to the extension of burn duration of $0-50 \%$ fuel mass. The $\mathrm{HC}$ emissions are higher for rich mixture due to incomplete combustion. For stoichiometric and lean mixtures the $\mathrm{HC}$ emissions are lower due to the consumption of all fuel injected into cylinder. The HC formation could be affected by engine misfiring, flame quenching, improper ignition timing, insufficient burning time and not burnable air/fuel mixture. Too lean or too rich mixture resulted in increased $\mathrm{HC}$ emissions. For the rich mixture the oxygen concentration is low, causing incomplete combustion of the fuel (hydrocarbons) injected to the cylinder and hence increased the $\mathrm{HC}$ emissions. The injected water reduces the fuel percentage in the mixture and increases the air amount introduced to the cylinder and consequently more amount of injected fuel will burn and lower HC will be produced. Similar results were confirmed by Hoppe et al. [2016]. In addition, the injected water reduced the peak burn rate leading to higher $\mathrm{HC}$ emissions.

The effect of water mass on the carbon dioxide and carbon monoxide emissions is presented in Figures 12 and 13. The $\mathrm{CO}_{2}$ and $\mathrm{CO}$ concentration decreased when the water flow mass increased.

As shown in Figure 13, the higher $\mathrm{CO}$ emissions presented for rich mixture due to insufficient oxygen in the mixture caused incomplete combustion and slow $\mathrm{CO}$ oxidation. As the oxygen amount increased (as for lean mixture) the $\mathrm{CO}$ emissions decreased. Besides, the $\mathrm{CO}$ emissions reduced significantly when the water flow mass was added to the mixture, compared to dry combustion for all AFR. When the water was injected to the engine port and introduced to the cylinder, the fuel enrichment conditions diminished resulting in lower
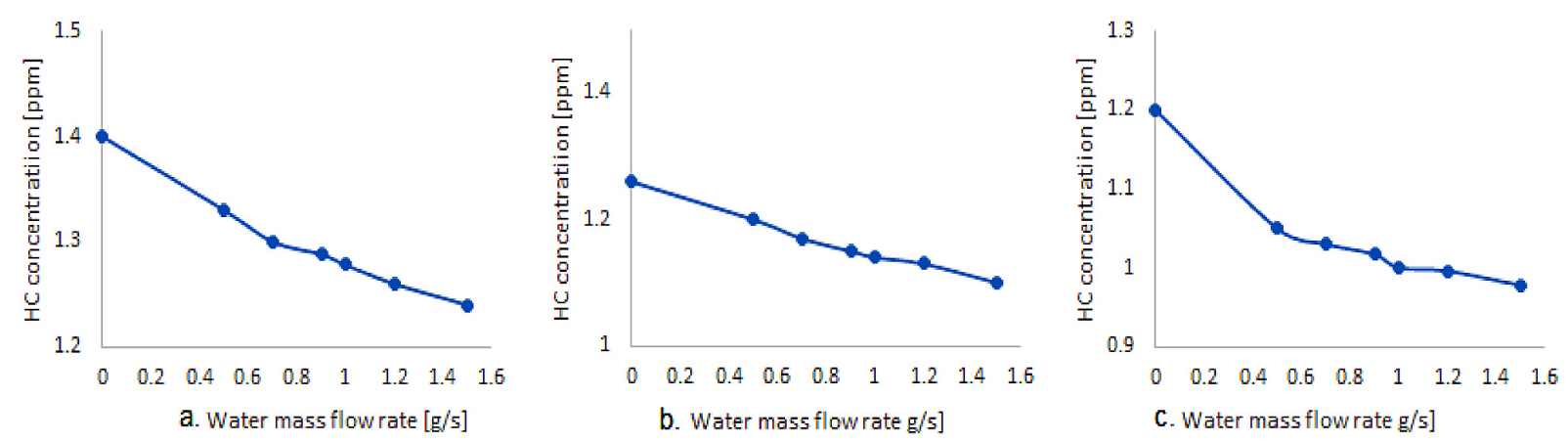

Figure 11. Effect of water injection on $\mathrm{HC}$ emissions (dry AFR, $\mathrm{a}=12.5, \mathrm{~b}=14.5$, and $\mathrm{c}=16.5$ respectively) 

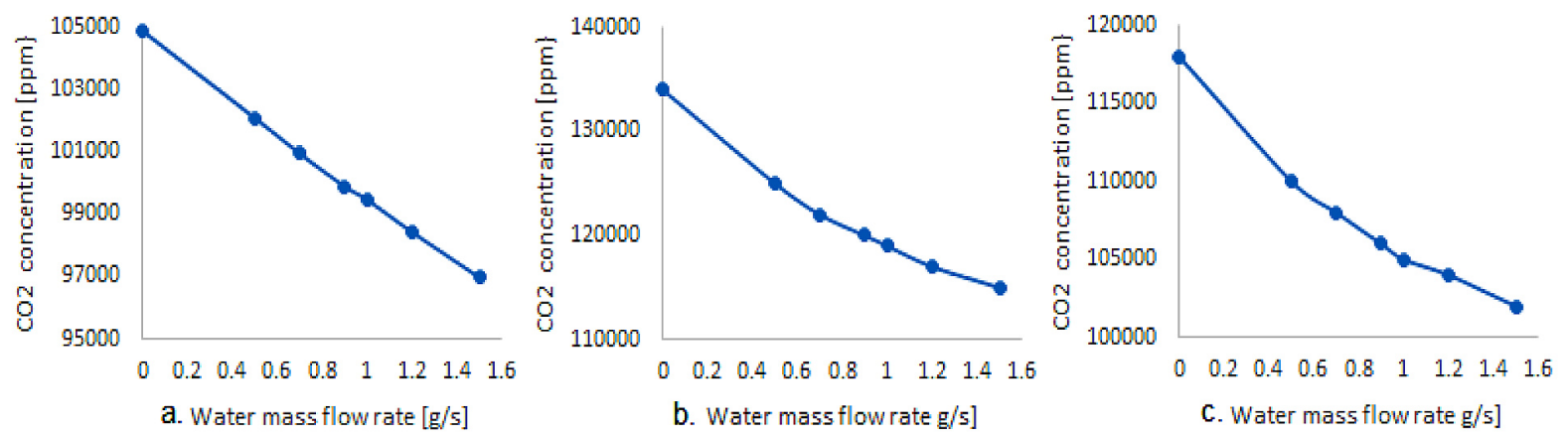

Figure 12. Effect of water injection on $\mathrm{CO}_{2}$ emissions (dry AFR, $\mathrm{a}=12.5, \mathrm{~b}=14.5$, and $\mathrm{c}=16.5$ respectively)
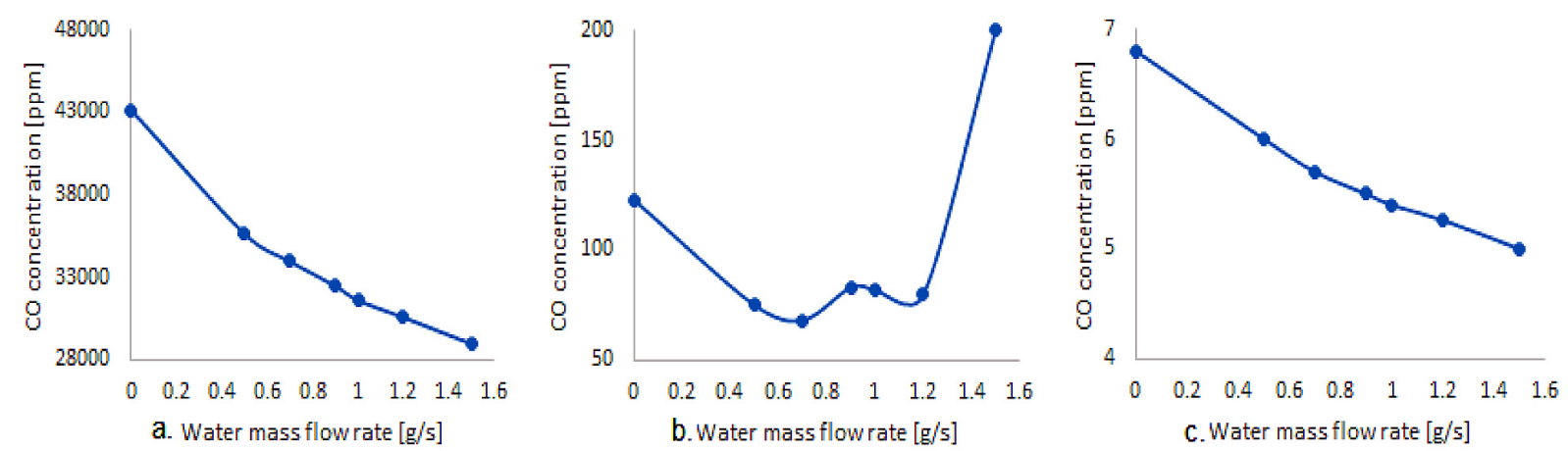

Figure 13. Effect of water injection on $\mathrm{CO}$ emissions (dry AFR, $\mathrm{a}=12.5, \mathrm{~b}=14.5$, and $\mathrm{c}=16.5$ respectively)

$\mathrm{O}_{2}$ available for $\mathrm{CO}$ oxidation. The same results were obtained by Kim et al. [2016]. In addition, water could decrease the emissions, if $\mathrm{CO}$ and water shift to produce $\mathrm{H}_{2}$ and $\mathrm{CO}_{2}$, as performed by Parley [2011].

\section{CONCLUSIONS}

As a result of the investigations, the following conclusions were drawn:

1. When injected, the water mass increased to the optimum value, the engine power and thermal efficiency increased respectively.

2. In general, the increase mass of injected water resulted in decreased engine emissions for different AFR.

3. The stoichiometric mixture produces higher engine power compared to other mixtures due to complete combustion.

4. Further addition of water inside the cylinder resulted in deteriorated engine performance and weaker combustion efficiency. Therefore, the mass of injected water should be limited to the optimum value for each engine operating conditions.

\section{REFERENCES}

1. Adnan R., Masjuki H.H., Mahlia T.M.L. 2012. Performance and emission analysis of hydrogen fueled compression ignition engine with variable water injection timing. Energy, 43, 416-426.

2. Berni F., Breda S., Lugli M., Cantore G. 2015. A numerical investigation on the potentials of water injection to increase knock resistance and reduce fuel consumption in highly downsized GDI engines. Energy Procedia, 81, 826-835.

3. Boretti A. 2013. Water injection in directly injected turbocharged spark ignition engine. Applied Thermal Engineering, 52 (1), 62-68.

4. Breda S., Berni F., D'Adamo A., Testa F., Severi E., Cantore G. 2015. Effects on knock intensity and specific fuel consumption of port water/methanol injection in a turbocharged GDI engine: Comparative analysis, Energy Procedia, 82, 96-102.

5. Brusca S. and Lanzafame R. 2003. Water injection in IC-SI engines to control detonation and to reduce pollutant emissions. SAE technical paper 2003-011912, https://doi.org/10.4271/2003-01-1912.

6. Harrington J. 1982. Water addition to gasoline effect on combustion, emissions, performance and knock. SAE technical paper 820314, https://doi. org/10.4271/820314.

7. Hoppe F., Thewes M., Baumgarten H., Dohmen J. 2016. Water injection for gasoline engines: Poten- 
tials, challenges, and solutions. International Journal of Engine Research, 17(1), 86-96

8. Kim J., Park H., Bae C., Choi M. and Kwak Y. 2016. Effects of water direct injection on the torque enhancement and fuel consumption reduction of a gasoline engine under high-load conditions. International Journal of Engine Research, 17(7), 795-808.

9. Lanzafame R. 1999. Water injection effects in a single-cylinder CFR engine. SAE technical paper 1999-01-0568, https://doi.org/10.4271/1999-010568 .

10. Lumsden G., Eddleston D., Sykes R. 1997. Comparing lean burn and EGR. SAE technical paper; 970505.

11. GT-Power site, http://www.gtisoft.com (access 20.06.2018).

12. Mathur H.B., Das L.M., Patro T.N. 1992. Effects of charge diluents on the emission characteristics of a hydrogen fueled diesel engine. International Journal of Hydrogen Energy, 17 (8), 635-642.

13. Parley W.J. 2011. Effects of water injection and increased compression ratio in a gasoline spark ignition engine. Thesis, University of Idaho.

14. Peters B. and Stebar R. 1976. Water-gasoline fuels - their effect on spark ignition engine emissions and performance. SAE technical paper 760547 , https://doi.org/10.4271/760547.

15. Subramanian K.A. 2011. A comparison of waterdiesel emulsion and timed injection of water into the intake manifold of a diesel engine for simultaneous control of NO and smoke emissions. Energy Conversion Management, 52, 849-857.

16. Tauzia X., Maiboom A., Shah S.R. 2010. Experimental study of inlet manifold water injection on combustion and emissions of an automotive direct injection diesel engine. Energy, 35, 3628-3639.

17. Tesfa B., Mishra R., Gu F., Ball A.D. 2011. Water injection effects on the performance and emission characteristics of a CI engine operating with biodiesel. Renewable Energy, 37, 333-344.

18. Totala N.B., Pratyush, Hussain A., Tajkhan M., Siddharth. 2013. Performance analysis of 4-stroke single cylinder SI engine and preheating gasoline and Injecting 50\% volume/volume water Methanol mixture in carburetor, Indian Journal of Applied Research, 3 (7), 293-296.

19. Weatherford W. and Quillian R. 1970. Total cooling of piston engines by direct water injection. SAE technical paper 700886, https://doi. org/10.4271/700886. 